\title{
Relevance knowledge and use of ICTs, electronic accounting of natural persons, in Monclova, Coahuila Mexico
}

\section{Relevancia conocimiento y uso de los tics, contabilidad electrónica de personas físicas, en Monclova, Coahuila México}

CRUZ-MACIAS, Raúl Ángel*†, CARMONA-MARTINEZ, Reynaldo, TERRAZAS-TAMAYO, Angelica Margarita, VÁZQUEZ LÚNDEZ Jorge Luis

Universidad Autónoma de Coahuila, Faculty of Accounting and Administration

ID $1^{\text {st }}$ Author: Raúl Ángel, Cruz-Macias / ORC ID: 0000-0002-6902-1278, CVU CONACYT ID: 998661

ID $1^{\text {st }}$ Coauthor: Reynaldo, Carmona-Martínez / ORC ID: 0000-0002-6960-0299, CVU CONACYT ID: 549393

ID $2^{\text {nd }}$ Coauthor: Angelica Margarita, Terrazas-Tamayo / ORC ID: 0000-0002-7081-3491, CVU CONACYT ID: 998662

ID $3^{\text {rd }}$ Coauthor: Jorge Luis, Vazquez-Lundez / ORC ID: 0000-0002-9256-5750, CVU CONACYT ID: 240054

DOI: $10.35429 / J E D T .2019 .5 .3 .8 .17$

Received September 10, 2019; Accepted December 20, 2019

\begin{abstract}
For natural persons with business and professional activity, information technologies are a basic and important activity in order to simplify the fulfilment of their tax obligations before SAT. For this reason, this paper focuses on whether the taxpayers are aware of the need to apply these techniques in support of the fulfillment of these obligations. For this project, we used a type of mixed research that combines theoretical content and an applied part, in which the opinions of 20 contributors to are analyzed. In view of taxpayers' lack of knowledge regarding these issues, we seek to offer an informed proposal that allows for better use and application of the management of electronic accounting as an essential contribution to taxpayers from the city of Monclova, Coah. (trade, 2018)
\end{abstract}

Electronic accounting, ICT'S, Tax obligations, SAT

\begin{abstract}
Resumen
Para las personas físicas con actividad empresarial, las tecnologías de información constituyen una actividad básica e importante con la finalidad de simplificar el cumplimiento de sus obligaciones fiscales ante SAT, por esta razón la presente investigación se enfoca para conocer si los contribuyentes están conscientes de las necesidades de aplicar estas técnicas en apoyo al cumplimiento de estas obligaciones, para el manejo del presente trabajo se utilizara una investigación de tipo mixto que combina una parte conceptual de contenido teórico y una parte aplicativa donde se analizan las opiniones de 20 personas contribuyentes del régimen de actividad empresarial, ante el desconocimiento que existe de los contribuyentes sobre estos temas busca ofrecer una propuesta fundamentada que permita un mejor uso y aplicación del manejo de la contabilidad electrónica como contribución esencial a los contribuyentes de Monclova, Coah. (comercio, 2018).
\end{abstract}

Contabilidad electrónica, TIC'S, Obligaciones fiscales, SAT

Citation: CRUZ-MACIAS, Raúl Ángel, CARMONA-MARTINEZ, Reynaldo, TERRAZAS-TAMAYO, Angelica Margarita, VÁZQUEZ LÚNDEZ Jorge Luis. Relevance knowledge and use of ICTs, electronic accounting of natural persons, in Monclova, Coahuila Mexico. Journal-Economic Development Technological Chance and Growth. 2019. 3-5: 8-17

\footnotetext{
* Correspondence to Author (email: cruzma17@ hotmail.com)

$\uparrow$ Researcher contributing first author.
} 


\section{Background}

Information and communication technologies (ICT) and electronic accounting have had the greatest impact on human development, since they involve many of the techniques, processes and the use of devices that human beings have developed throughout history: from the creation of writing, printing, languages, paper, to the creation of computers, software, and communication networks that allow people to create, preserve, improve, distribute and, above all, share knowledge in an accurate, accelerated and boundless manner.

It is for this reason that, due to Information and Communication Technologies, the world is changing more and more quickly, as these technologies are also changing their paradigms. An example of this is the means and the way in which people can communicate, entertain and work today, using social networks, mobile devices and e-commerce.

At the same time, the business world has become more dynamic and competitive due to the proper use of electronic accounting, as companies with good computer systems, communication networks and services tend to be more competent than those with obsolete systems that are far from being competent, as services are often slow and less efficient. In this digital era, it has been of utmost importance to optimize processes and significantly reduce the time of obtaining and analyzing information that allows owners, shareholders and senior executives to make more accurate decisions and to make their reports and tax formalities more successful, this situation has already been extended to individuals.

By experience in the city of Monclova Coahuila, the natural persons in general visualize the use of the electronic accounting as extremely important, but for most of them there is little generalized knowledge about its use and application.

For natural persons with business activities, information technologies are a basic and important activity in order to simplify the fulfilment of their tax obligations before SAT (Tax Administration Service). For this reason, this paper focuses on whether the taxpayers are aware of the need to apply these techniques in support of the fulfillment of these obligations.
For this project, we used a type of mixed research that combines theoretical content and an applied part, in which the opinions of 20 contributors to are analyzed. In view of taxpayers' lack of knowledge regarding these issues, we seek to offer an informed proposal that allows for better use and application of the management of electronic accounting as an essential contribution to taxpayers from the city of Monclova, Coahuila. (trade, 2018)

Keywords: Electronic accounting, ICT'S, Tax obligations, SAT.

How much do you know about the application of electronic accounting?

How useful is the use of electronic accounting for individuals?

In simplifying the information needed to inform the authority (SAT), how important is the use?

How familiar are you with the implications of not keeping electronic accounts?

How familiar are you with the use of electronic accounting?

How much does not knowing about procedures such as electronic invoicing in compliance with your tax obligations affect you?

How much do you know about the Authorized Certification Provider of (ACP) Words as part of electronic accounting?

How much do you know about electronic accounting software?

Have you considered the acquisition, configuration and maintenance of electronic accounting software in the costs of your business?

Have you considered the acquisition, configuration and maintenance of the electronic accounting software in your business costs?

How much have you considered training your staff to handle the electronic accounting of your business? 


\section{Theoretical framework}

This section of the paper presents the initial theoretical framework. For this purpose, it was necessary to carry out a complete bibliographical review by specialists in the central subject of this research. The complicated study of fiscal provisions achieves its analysis by starting with the investigative background carried out by highly prestigious researchers, allowing us to define central concepts. These contributions are based on real and concrete cases that were studied at the time, using methodological thoroughness.

Companies provide useful financial information for decision making, however, this is obtained through accounting. (Andrade, 2014) state that, at present, companies cannot compete without efficient information systems, and among these they emphasize accounting. They point out that the objective of accounting is to generate and communicate useful information for appropriate decision-making by a business' creditors and shareholders, as well as by other groups interested in the financial situation of companies.

The financial information is really useful for decision making in companies and is strategic because by giving this type of use to financial information, the result will be perceived in the short term, since it is a tool that supports the strategy and competitiveness in the organization (Ramirez, 2010) Lara Flores and Lara (Ramirez L. Lara Flores and Lara (Ramirez L., 2010), emphasize that accounting, as financial information, has been considered as art, science, technique and discipline, words with meanings necessary to know in order to apply in the definition of accounting, to consider the more convenient; they also point out that accounting is the discipline that teaches the rules and procedures to analyze, classify and record the operations carried out by economic entities integrated by a single individual, or constituted under the form of companies with commercial, industrial, banking or cultural, scientific, sports, religious, union, government activities, etc., and which serves as a basis for preparing financial information that is useful to the general user in making economic decisions.
Economic globalization has led to the harmonization of accounting standards throughout the world, in order to generate financial information that is comparable in content regarding the performance of economic entities, and that in turn is easy to interpret.

In Mexico, as in other countries, there is a committee in charge of carrying out research and monitoring processes among the financial and business community and other interested sectors, considering, of course, current international standards; this committee is the Mexican Council for Research and Development of Financial Reporting Standards, A.C. (CINIF), which has established the Financial Reporting Standards (NIF) to replace the Generally Accepted Accounting Principles (PCGA); the NIFs, which came into effect on January 1, 2006, are the result of a substantial revision and update to PCGA, (Lara Flores and Lara Ramirez 2010, p. 10).

In this sense, the definition of financial accounting according to NIF A-1 of the CINIF, called "Structure of Financial Reporting Standards," states that accounting is a technique used to record the operations that economically affect an entity and that systematically and structurally produces financial information. Operations that economically affect an entity include transactions, internal transformations and other events.

Under this perspective (Bernes, 2013) Montejo Bernes and Montejo Bernes (2013), point out that accounting is a technique, even though there has been much discussion about whether it constitutes a science; in reality, it is a technique because it was created by man as a means to obtain financial information from an economic entity, and it does not have the characteristics of a science, such as objectivity and generality, even more so that many operations carried out by an economic entity are affected by the subjective criteria of the accountant or decision maker, regarding its application and recording in the accounting books. Financial reporting, according to the Financial Accounting Standard Board (FASB), as cited by (Lopez, 2007) Romero López (2007), pursues three fundamental objectives: 
1) to provide useful information for current and potential investors and creditors, as well as for other users who need to make rational investment and credit decisions, 2) to prepare information that will help users determine the amounts, timing and uncertainty of cash inflow projects associated with making investments in the enterprise, (3) to report on an enterprise's economic resources, rights over those resources, and the effects of transactions and events that change those resources and rights over those resources.

Electronic accounting is the translation of part of the accounting information into files in XML format, which can be reviewed by the tax authority. There are three concepts to consider: 1. Taxpayers must deposit their Catalogue of Accounts in the SAT Tax Mailbox, showing equivalences with a universal catalogue published by the tax authority. This must be done each time it is modified. 2. They must also register the Balance of Payments in said mailbox on a monthly basis. 3. Finally, when the authority requests it, they shall register in the Tax Mailbox all the Policies in a given period of time, in XML format.

Lara Flores and Lara Ramírez (2010) state that in most countries the laws and regulations that establish the obligation to keep accounts are modified and added as economic, political, social and cultural changes occur. Under this perspective, in Mexico, the obligation to keep accounts is set out in Article 33 of the Commercial Code (CC), which declares the following:

The trader is obliged to keep and maintain an adequate accounting system. This system may be kept using the instruments, resources and registration and processing systems that best suit the particular characteristics of the business, but in any case, it must meet the following minimum requirements: It must make it possible to identify individual operations and their characteristics, and to connect these individual operations with the original supporting documents. It must allow the traceability from individual operations to the accumulations that result in the final figures of the accounts and vice versa; it must allow the preparation of the statements that are included in the financial information of the business.
It must allow the connection and traceability between the figures of said statements, the accumulations of the accounts and the individual operations; it must include the internal control and verification systems necessary to prevent the omission of the operations record, to ensure the correctness of the accounting record and to ensure the correctness of the resulting figures.

However, one of the major tax changes for the year 2014, was the one related to electronic accounting, so it is of vital importance to study this new obligation, the validity of which originally began on July 1, 2014 for some taxpayers with their respective extensions. In recent years, we have witnessed various adjustments in tax matters, in accordance with the evolution of the technological tools used by SAT as a collection instrument.

As examples, we can mention the following cases: submission of notices to the federal taxpayer registry through electronic means, the use of advanced electronic signature, preparation and submission of online returns, automatic federal tax returns, payment of contributions through electronic transfers, notices by electronic means (tax mailbox), etc., in which the common denominator is the use of electronic means to replace traditional paperbased procedures. Substantive tax laws, such as the (Tributaria, 2019) Income Tax Law (LISR), Value Added Tax Law (LIVA), among others, are those that impose on taxpayers the obligation to keep accounts, which they generally refer to the CFF for the purposes of regulation, in accordance with the following provision of the LISR.

Article 28. Persons who are obliged to keep accounts under the tax provisions shall be subject to the following:

I. For tax purposes, the accounting is integrated by:

A. The accounting books, systems and records, working papers, statements, special accounts, social books and records, inventory control and valuation method, disks and tapes or any other processable means of data storage, the equipment or electronic systems of tax registration and their respective records, in addition to the documentation proving the respective entries. 
As well as all documentation and information related to compliance with the tax provisions, which accredits their income and deductions, and that is required by other laws; The Regulations of this Code shall establish the documentation and information with which this section must be complied with, and the additional elements that make up the accounting.

B. In the case of persons who manufacture, produce, process, transport, store, including storage for their own use, distribute or dispose of any type of hydrocarbon or oil, in addition to the above, must have the equipment and computer programs to carry out volumetric controls, as well as the reports issued by a test or trial laboratory, which determine the type of hydrocarbon or oil in question, and the octane rating in the case of gasoline. Volumetric controls of the products referred to in this paragraph are understood to be the records of the volume, object of their operations, including their stocks, which will form part of the taxpayer's accounts.

The computer equipment and software to carry out volumetric controls shall be those authorized for such purpose by the Tax Administration Service (SAT), which must always be kept in operation.

The taxpayers referred to in this paragraph are obliged to ensure that the equipment and software for volumetric checks always operate correctly. For such purpose, they must acquire said equipment and programs, obtain the certificates that accredit their correct operation and functioning, as well as obtain the laboratory reports indicated in the first paragraph of this section, from the persons authorized by the Tax Administration Service for such purposes.

The suppliers of equipment and software to carry out volumetric controls or to provide services to verify the correct operation and functioning of the equipment and software, as well as the test or trial laboratories to provide the services of issuing reports on the goods specified in the first paragraph of this section, shall be authorized by the Tax Administration Service, in accordance with the general rules issued by the latter for such purposes.
The Tax Administration Service shall revoke the authorizations referred to in the previous paragraphs, when in the cases provided for in the rules indicated in the previous paragraph, any of the obligations established in the respective authorization or in this Code are not complied with.

The technical characteristics of the volumetric controls and the laboratory reports referred to in this section shall be made in accordance with the general rules issued by the Tax Administration Service, taking into consideration the Mexican Official Standards related to hydrocarbons and oil products issued by the Energy Regulatory Commission.

II. The accounting records or entries referred to in the previous section shall comply with the requirements established in the Regulations of this Code and the general provisions issued by the Tax Administration Service.

III. The records or entries that make up the accounting shall be kept on electronic media in accordance with the Regulations of this Code and the general provisions issued by the Tax Administration Service. The supporting documentation for such records or entries shall be available at the tax address of the taxpayer.

IV. They shall enter their accounting information on a monthly basis through the Tax Administration Service's website, in accordance with general rules issued for such purpose.

ARTICLES 33 AND 34 OF THE REGULATIONS OF THE FISCAL CODE OF THE FEDERATION

Article 33.- For the purposes of Article 28, Sections I and II of the Code, the following shall apply:

A. The documents and information that make up the accounting are:

I. The auxiliary accounting records or entries, including the catalog of accounts used for such purpose, as well as the policies of such records and entries;

II. Notices or applications for registration in the Federal Taxpayer Registry, as well as their supporting documentation; 
III. Annual, informative and provisional, monthly, bimonthly, quarterly or final payment declarations;

IV. Bank statements and reconciliations of deposits and withdrawals with respect to accounting records, including statements of account corresponding to investments and credit, debit or service cards of the taxpayer, as well as electronic purses used for the payment of fuel and for the granting of food vouchers that, as the case may be, are granted to workers of the taxpayer;

V. Shares, corporate shares and debt securities to which the taxpayer is a party;

VI. The documentation related to the hiring of individuals who provide subordinate personal services, as well as that related to their registration and recording, or notices made regarding social security and their contributions;

VII. Documentation related to imports and exports in customs or foreign trade matters;

VIII. Documentation and information from the records of all operations, acts or activities, which shall be recorded in accordance with the necessary internal control and verification systems; and

IX. Any other declarations that they are obliged to make in terms of the applicable tax provisions.

\section{B. Accounting records or entries must:}

I. Be analytical and be made in the month in which the operations, acts or activities to which they refer are carried out, at the latest within five days following the performance of the operation, act or activity;

II. All transactions, acts or activities must be entered in the daily book in a descriptive manner, following the chronological order in which they are carried out, indicating the debit or credit movement corresponding to each one, as well as the names of the accounts, their balance at the end of the immediately preceding registration period, the total debit or credit movement to each account in the period and its final balance.
Daily and general books may be kept by establishment or dependency, by type of activity or by any other classification, but in all cases, there must be daily and general books in which all the taxpayer's operations are gathered;

III. Allow the identification of each operation, act or activity and its characteristics, relating them to the folios assigned to the tax vouchers or with the supporting documentation, in such a way that the form of payment, the different contributions, rates and fees can be identified, including those operations, acts or activities for which contributions are not due, according to the operation, act or activity in question;

IV. Allow the identification of the investments made by relating them with the supporting documentation or with the tax vouchers, in such a manner that the date of acquisition of the good or of the investment made, its description, the original amount of the investment, the percentage and amount of its annual deduction, if any, as well as the date of commencement of its deduction, may be specified;

V. Relate each transaction, act or activity with the balances that result in the final figures of the accounts;

VI. Formulate the statements of financial position, income, changes in stockholders' equity, origin and application of resources, as well as the balances for verification, including the memorandum accounts and the notes to such statements

VII. Relate the statements of financial position with the accounts of each operation;

VIII. Identify the contributions to be cancelled or returned, by virtue of returns received and discounts or allowances granted in accordance with tax provisions;

IX. Verify compliance with the requirements regarding the granting of fiscal incentives and subsidies; 
X. Identify the goods, distinguishing, among those acquired or produced, those corresponding to raw materials and finished or semi-finished products, those disposed of, as well as those intended for donation or, as the case may be, destruction;

XI. The Company shall be registered in the Spanish language and the values in the national currency shall be recorded.

When the information on the tax receipts or data and documentation that make up the accounting system is in a language other than Spanish, or the values are recorded in foreign currency, they must be accompanied by the corresponding translation and indicate the exchange rate used for each operation;

XII. Establish by cost center, identifying the operations, acts or activities of each branch or establishment, including those located abroad;

XIII. Indicate the date of execution of the operation, act or activity, its description or concept, the amount or unit of measurement as the case may be, the form of payment of the operation, act or activity, specifying if it was cash, credit, installment or partial, and the means of payment or extinction of such obligation, as the case may be.

In the case of credit, instalment or partial transactions, each payment or credit received or made, including the advance or down payment, as appropriate. In addition to the above, they must record the amount of the payment, specifying whether it is made in cash, interbank transfer of funds, nominative check for account deposit, debit, credit or service card, electronic purse or by any other means. When payment is made in kind or in exchange, the type of goods or services provided as consideration and their value must be indicated;

XIV. Allow identification of deposits and withdrawals in bank accounts opened in the name of the taxpayer and reconcile them with the operations performed and their supporting documentation, such as statements issued by financial institutions;
XV. The records of inventories of goods, raw materials, products in process and finished products, in which control shall be maintained, that allow the identification of each unit, type of goods or product in process and date of acquisition or disposal as the case may be, as well as the increase or decrease in said inventories and the stocks at the beginning and end of each month and at the close of the fiscal year, specifying the date of delivery or receipt, as well as whether it is a return, donation or destruction, when these cases occur.

For purposes of the preceding paragraph, inventory control must identify the valuation method used and the date as of which it is used, whether it is the first-in first-out method, last-in first-out method, identified cost, average cost or retail cost, as applicable;

XVI. Records relating to the option of deferral of the causation of contributions in accordance with tax provisions, if financial lease contracts are entered into such records, shall allow the identification of the corresponding part of the operations in each fiscal year, including memorandum accounts;

XVII. The control of donations of goods received by authorized donators in terms of the Income Tax Law, which shall allow the identification of donors, goods received, goods delivered to their beneficiaries, recovery fees obtained for goods received as donations and the record of destruction or donation of goods or merchandise in the fiscal year in which they are made; and

XVIII. Contain the value added tax that has been transferred to the taxpayer and that which has been paid on the import, corresponding to the part of its expenses and investments, in accordance with the following assumptions:

a. The acquisition of goods, services and the temporary use or benefit of goods, which are used exclusively to carry out their activities for which they must pay the tax;

b. The acquisition of goods, services and the temporary use or benefit of goods, which are used exclusively to carry out their activities for which they do not have to pay tax; and 
c. The acquisition of goods and services and the temporary use or benefit of goods, which are used both for activities for which the tax is payable and those for which the tax is not payable.

When the destination of the goods or services varies and the adjustment of the credit provided for in Article 5.-A of the Value Added Tax Law must be made, its effect must be recorded in the accounts.

Article 34.- For the purposes of Article 28 , Section III of the Code, the taxpayer must keep and store as an integral part of its accounting all the documentation relating to the design of the electronic system where it stores and processes its accounting data and the diagrams thereof, making available to the Tax Authorities the equipment and its operators so that they may assist them when they exercise their powers of verification and, where appropriate, must comply with the corresponding Official Mexican Standards relating to the generation and conservation of electronic documents.

The taxpayer who is in suspension of activities must keep their accounting at the last address stated in the federal registry of taxpayers and, if they later vacate the address stated in the aforementioned registry, they must present the notice of change of tax address, in which they must keep their accounting during the period established in Article 30 of the Code.

Taxpayers may choose to back up and keep their accounting information on optical disks or any other electronic means that the Tax Administration Service may authorize by means of general rules.

\section{Objectives}

- To know and apply the opinion of individuals when using electronic accounting.

- To know the number of natural persons of businesses that would be willing to accept and to apply the electronic accounting in the city of Monclova, Coahuila.

- To know if the users are properly trained to apply and handle electronic accounting.

\section{Scope}

The scope of this study relates to learning by means of a measurement instrument the degree in which the businesses of the locality of Monclova know and apply the electronic accounting for the fulfillment of their fiscal obligations.

\section{Problem detected}

In the business community of the town of Monclova, Coahuila, there is a lack of knowledge that the businesses have with respect to the use and application of electronic accounting for the fulfillment of the fiscal obligations, which hinders the elaboration of the necessary reports.

\section{Type of research}

The present work is classified as exploratory descriptive, because it presents its components and its manifestation; it is analytical and explanatory, as a study, presenting explanations AS A CONCLUSION reasons and generates a set of actions to propose solutions to the presented problem.

\section{Hypothesis}

$\mathrm{H}_{1}$ If individuals are convinced and aware that electronic accounting promotes compliance and simplification of tax obligations, then businesses will gain greater efficiency in time and money to meet those obligations.

$\mathrm{H}_{0}$ If individuals are unaware of the use and applications of electronic accounting, it favors compliance with tax obligations, as well as maintaining greater efficiency in the fulfilment of such obligations.

\section{Variables}

\section{1.- General knowledge}

2.- Technical knowledge to use electronic accounting

3.- Resources required

4.- Technical and accounting consultation

5.- Costs of electronic accounting

6.-Lack of knowledge regarding the handling of ICTs. 


\section{Methodological Analysis}

\section{Sample Applied to the Study}

A sample of twenty businesses located in the town of Monclova, Coahuila in the center of the state of Coahuila Mexico was randomly selected.

\section{Measuring instrument}

A ten-question instrument was applied to twenty businesses of various types in the town of Monclova, Coahuila using a Likert scale. Where Nothing $=1, \quad$ Slightly=2, Moderately $=3$, Considerably $=4$, Completely $=5$. the following variables:

\section{General knowledge \\ 2. Technical knowledge \\ 3. Resource requirements}

The questions on the questionnaire are the following:

How much do you know about the application of electronic accounting?

How useful is the use of electronic accounting for your business?

In simplifying the information needed to inform the authority (SAT), how important is the use?

How much do you know about the implications of not doing electronic accounting?

How familiar are you with the use of electronic accounting?

How much are you affected by the lack of knowledge of procedures such as electronic invoicing in compliance with your tax obligations?

How much do you know about Authorized Certification Providers (ACP) as part of electronic accounting?

How much do you know about electronic accounting software?

In the costs of your business, have you considered the acquisition, configuration and maintenance of electronic accounting software?
How much have you considered the training of your staff to manage the electronic accounting of your business?

\section{Applied Tests}

\section{Analysis and results}

1.- Instrument reliability analysis

\begin{tabular}{|ll|l|l|}
\hline & $\mathrm{N}$ & $\%$ \\
\hline Cases & Valid & 20 & 100.0 \\
\hline & Excluding & 0 & 0.0 \\
\hline & Total & 20 & 100.0 \\
\hline
\end{tabular}

Table 1 Case Processing

\begin{tabular}{|l|l|}
\hline Cron Bach's alpha & N of elements \\
\hline 0.824 & 10 \\
\hline Confidence level & \\
\hline
\end{tabular}

Table 2 Reliability statistics

2.- Frequency analysis (frequency and percentage table)

The most important questions are:

How much do you know about the application of electronic accounting?

Have you considered the acquisition, configuration and maintenance of electronic accounting software in your business costs?

How much have you considered the training of your staff to handle the electronic accounting of your business?

\begin{tabular}{|l|l|l|l|}
\hline & P1 & P8 & P10 \\
\hline Nothing & 3 & 5 & 5 \\
\hline Slightly & 8 & 7 & 3 \\
\hline Moderately & 6 & 8 & 5 \\
\hline Considerably & 2 & 0 & 6 \\
\hline Completely & 1 & 0 & 1 \\
\hline
\end{tabular}

$50 \%$ of the opinion is moderately aware of the application of electronic accounting

Table 3 Selection of the best 3

\begin{tabular}{|l|r|r|r|}
\hline Nothing & $15 \%$ & $25 \%$ & $25 \%$ \\
\hline Slightly & $40 \%$ & $35 \%$ & $15 \%$ \\
\hline Moderately & $30 \%$ & $40 \%$ & $25 \%$ \\
\hline Considerably & $10 \%$ & $0 \%$ & $30 \%$ \\
\hline Completely & $5 \%$ & $0 \%$ & $5 \%$ \\
\hline
\end{tabular}

Table 4 Frequency 
Regarding question one, how much do you know about the application of electronic accounting?

The highest percentage was that fifty percent of the opinions obtained in the instrument indicated that they known moderately, therefore fifty percent do not know it, on the other hand, for question number eight, How much do you know about the handling of electronic accounting software?, sixty-three percent indicated that they know moderately, although there is was thirteen percent that indicated that they have no knowledge; in the same way, for question number ten, How much have you considered the training of your staff to handle the electronic accounting of your business?, Fifty percent of the opinions indicated that they know the extent of the training needs, although thirteen percent indicate slightly.

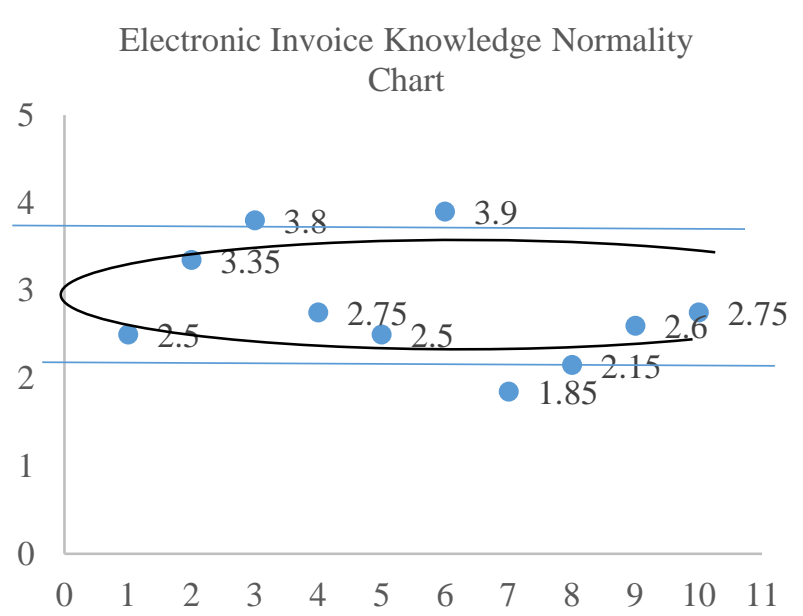

Variables 3 (3.8) and 6 (3.9) are over the upper limit, in which most respondents know the implications of electronic accounting and the providers that offer it, however, variable $7(1.85)$ is over the lower limit and means that most respondents do not have knowledge and application of software, the rest of the variables are within the norm.

Graph 1 Analysis of data normality

\section{Conclusions}

In relation to the general concepts, we used a mixed-type investigation, which combines a conceptual part of theoretical content, in which we detected the lack of knowledge that the businesses have with respect to the use and application of electronic accounting for the fulfillment of their fiscal obligations, hindering the elaboration of the necessary reports.
Therefore, accepting Hypothesis 1 and rejecting Hypothesis 2, it is evident that individuals with knowledge of electronic accounting comply with their obligations in an easier way, in the business community of the town of Monclova, Coahuila.

And on the other hand, applicative, since the opinions of 20 taxpayers of the business activity regime were analyzed.

Considering that $37.3 \%$ of the interviewees do not have knowledge nor use electronic accounting, it would be interesting to develop a simple application that contributes to the generation of knowledge in a friendly and fun way, in order to fulfill responsibly their fiscal obligations.

\section{References}

Andrade, G. y. (2014). Conatbilidad . En A. y. gGuajardo, Contabilidad.

Bernes, M. (2013). Contabilidad. En M. Bernes, Contabilidad.

comercio, E. e. (MAY-AUGUST, 2018). contabilidad electronica. PÉREZ-SÁNCHEZ E., AVALOS-DÍAZ A., pp. 246-266 .

Lopez, R. (2007). Contabilidad. En R. Lopez, Contabilidad.

Ramirez, L. (2010). Contabilidad. En L. Ramirez, Contabilidad.

Ramirez, L. F. (2010). Contabilidad. En L. F. Ramirez, Contabilidad.

Tributaria, S. d. (2019). Ley de impuesto sobre la renta. Ley de impuesto sobre la renta. Mexcio. 